\title{
Mentha longifolia in vitro cultures as safe source of flavouring ingredients
}

\author{
Alessandra Bertoli ${ }^{\boxplus}$, Michele Leonardi ${ }^{1}$, Justine Krzyzanowska², Wieslaw Oleszek² \\ and Luisa Pistelli ${ }^{1}$ \\ 'Department of Pharmaceutical Science - University of Pisa, Pisa, Italy; ${ }^{2}$ Department of Biochemistry Institute of Soil Science and Plant Cultiva- \\ tion State Research Institute, Pulawy, Poland
}

\begin{abstract}
In vitro plantlets and callus of $M$. longifolia were established and their volatile constituents characterized by GC-MS analysis of their headspaces (HSs) and essential oils (EOs). Significant quali-quantitative differences were found in the aromatic fingerprints in comparison with the $M$. longifolia parent plants. In fact, limonene and carvone were the main constituents in the EOs of the mother plants, while the aroma of the in vitro plant material were especially enriched in oxygenated terpenes. In particular, huge amounts of piperitenone and piperitenone oxide $(75 \%)$ were found for in vitro plantlets, while trans-carvone oxide (19\%) and trans-piperitone epoxide $(9 \%)$ were found in callus EO. However, the established in vitro plant material showed lack of pulegone and menthofurane, thus preserving an important feature observed in the volatile fingerprint of the parent plants. In fact, because of their well-known toxicity significant amounts of pulegone and menthofurane may compromise the safety using of mint essential oil. Therefore the in vitro $M$. longifolia plantlets and callus may be regarded as a potential source of a safe flavouring agent.
\end{abstract}

Keywords: M. longifolia, in vitro plantlets, callus, essential oil, static headspace, GC-MS

Received: 11 August, 2011; revised: 02 November, 2011; accepted: 13 December, 2011; available on-line: 15 December, 2011

\section{INTRODUCTION}

Mentha longifolia L. (Lamiaceae) or wild mint is a perennial herb, extremely variable both morphologically and chemically. It comprises a number of isolated populations extending over the whole of Europe, and from African highlands down to the Cape of Good Hope (Lawrence, 1981). The aerial parts of adult plants are commonly used in folk medicine for the treatment of cold, cough, asthma, and chest inflammations, including pulmonary tuberculosis. It is also used externally to treat wounds and swollen glands (Ikram \& Haq, 1980; Evans, 1996; Mimica-Dukic et al., 1996; 2003). Mint extracts are commonly used as food flavoring additive and are generally considered safe to use as they provide good defense against oxidative damage and health benefits (Dorma et al., 2003). However, a revision of the safety aspects of some mint constituents such as pulegone and menthofurane has been discussed recently (Nair, 2001; JECFA, 2009). M. longifolia is known also under synonymous names as $M$. spicata var. longifolia $L$. or $M$. sylvestris. The majority of $M$. longifolia chemotypes and subspecies contain piperitenone oxide, piperitone oxide, carvone, menthone, and 1,8-cineol as the main constituents, even though major variation in the dominating compounds has been found in wild or cultivated plant material grown in different habitats (Maffei, 1988; Venskutonis et al., 1996; Fleisher \& Fleisher, 1998; Karousou et al., 1998; Baser et al., 1999; Abu Al-Futuh et al., 2000; Mastelic \& Jerkovic, 2002; Jaimand \& Rezaee, 2002; Rasooli \& Rezaei, 2002; Mathela et al., 2005; Oyedeji \& Afolayan, 2006; Gulluce et al., 2007). A summary of literature data on the essential oil (EO) composition of $M$. longifolia is reported in Table 1.

In the present study, leaves and stems of $M$. longifolia selected from cultivated adult plants (Pulawy, Poland) were used as mother plants to establish in vitro plantlets and callus. Both the headspaces (HSs) and the essential oils (EOs) were studied to compare the complete aromatic fingerprint of in vivo and in vitro biomass. To our knowledge, no studies have been reported on the volatile profile of in vitro cultures of $M$. longifolia.

\section{MATERIAL AND METHOD}

Plant Material. Seeds of Mentha longifolia (catalogue number: 239112) were obtained from the National Centre for Plant Genetic Resources at the Plant Breeding and Acclimatization Institut (Radzikow, Poland). Plants were cultivated in an experimental field of the Institute of Soil Science and Plant Cultivation in Pulawy, Poland. Plants were harvested at the beginning of flowering.

Seed sterilization and sowing. Seeds were washed in running tap water and sterilized with $70 \%$ ethanol for 2 min, then transferred to $10 \%$ perhydrol solution with shaking for $20 \mathrm{~min}$, and finally rinsed three times with sterile distilled water. Sterilized seeds were placed for germination on half-strength LS basal medium (Linsmayer \& Skoog, 1965) supplemented with $15 \mathrm{~g} \mathrm{~L}^{-1}$ sucrose and solidified with agar $6 \mathrm{~g} \mathrm{~L}^{-1}$, adjusted to $\mathrm{pH} 5.8$ followed by autoclaving at $121^{\circ} \mathrm{C}$ and $0.1 \mathrm{MPa}$ for $20 \mathrm{~min}$. Seeds were sown on the medium in Petri dishes and then were incubated in a growth chamber at $25^{\circ} \mathrm{C}$, under 16 hours light /8 hours dark cycle provided by fluorescent lamps. Sprouting seeds were planted on LS medium enriched

e-mail: bertoli@farm.unipi.it

Abbreviations: EO, essential oils; HS, headspace, GC-EI/MS, gas chromatography-electronic impact/mass detector; GC-Cl/MS, gas chromatography-chemical ionization/mass detector; LRI, linear retention index; SPME, solid phase microextraction. 
Table 1. EO yields collected in different countries.

\begin{tabular}{|c|c|c|c|}
\hline EO yield & Plant material & Reference & Region \\
\hline $1.63 \%\left(\mathrm{w} / \mathrm{w}_{\text {dry weight }}\right)$ & $\begin{array}{l}\text { dry mature plant } \\
\text { (no flowers) }\end{array}$ & Oyedeji \& Afolayan, 2006 & South Africa \\
\hline $1.09 \mathrm{~mL} / \mathrm{Kg}$ & fresh plant & Maffei, 1988 & Italy \\
\hline $0.93 \%(w / w)$ & fresh aerial parts & Rasooli \& Rezaei, 2002 & Iran \\
\hline $0.4-0.8 \%(w / w)$ & fresh leaves & Mathela et al., 2005 & India \\
\hline $2.31 \mathrm{~mL} / 100 \mathrm{~g}$ & air dried plant & Gulluce et al., 1996 & Turkey \\
\hline $3.5 \mathrm{~mL} / 100 \mathrm{~g}$ & air dried leaves & Jaimand \& Rezaee, 2002 & Iran \\
\hline $9.6 \mathrm{~mL} / 100 \mathrm{~g}$ & air dried flowers & Jaimand \& Rezaee, 2002 & Iran \\
\hline $0.93 \%(w / w)$ & air dried plant & Mastelic \& Jerkovic, 2002 & Croatia \\
\hline $0.43 \mathrm{~mL} / 100 \mathrm{~g}$ & air dried plant & Veskuntonis et al., 1996 & Lithuania \\
\hline $1.80 \mathrm{~mL} / 100 \mathrm{~g}$ & air dried plant & Kokkini et al., 1988 & Greece \\
\hline $1.6 \mathrm{~mL} / 100 \mathrm{~g}$ & air dried plant & Karousou et al., 1998 & Greece \\
\hline $0.1-1 \%(v / w)$ & fresh plant & Baser et al., 1999 & Turkey \\
\hline $\begin{array}{l}2.2 \pm 0.5 \% \mathrm{v} / \mathrm{w} \\
1.6 \pm 0.1 \% \mathrm{v} / \mathrm{w}\end{array}$ & $\begin{array}{l}\text { adult plant stems } \\
\text { adult plant leaves }\end{array}$ & Present study & Poland \\
\hline $\begin{array}{l}0.2 \pm 0.02 \% \mathrm{v} / \mathrm{w} \\
0.4 \pm 0.07 \% \mathrm{v} / \mathrm{w}\end{array}$ & $\begin{array}{l}\text { in vitro plantlets } \\
\text { callus tissue }\end{array}$ & Present study & in vitro biomass \\
\hline
\end{tabular}

were observed. Calli were subcultured at four-week intervals. For biochemical analysis calli from 7 th passage were used.

Phytochemical analysis. Chemicals. Commercial standards and isolated compounds from aromatic plant species were part of a homemade database of volatiles where each compound was used as reference material after GC-MS grade purity determination (98$99 \%)$. The samples and standard solutions were prepared using $n$ hexane (Carlo Erba, HPLC-grade).

Extraction procedure. Freezedried plant samples were hydrodistilled ( 2 h, 2 L distilled water, flow $2.0 \mathrm{ml} / \mathrm{min}$ ) by a Clevenger apparatus described in the European Pharmacopoeia V Ed. The essential oils were dissolved in Et2O, dried over anhydrous $\mathrm{MgSO} 4$, filtered and the solvent removed by evaporation on a water bath. The essential oil yields are summarised in Table 1. The essential oils were diluted in $n$-hexane (HPLC solvent with $0.2 \mathrm{mg} \mathrm{L}^{-1} \mathrm{NAA}$ (naphtaleneacetic acid) and $0.2 \mathrm{mg}$ $\mathrm{L}^{-1}$ IAA (indole-3-acetic acid). Flasks were kept in the growth chamber under the same conditions. Young in vitro plants were used for callus induction. Some of those plants after 30 days of cultivation were harvested, freezedried and used for biochemical analysis.

Callus induction. Leaves from 3-week-old in vitro plants were used as explants. They were cut into small pieces and transferred on several media variants supplemented with dichlorophenoxyacetic acid (2,4-D) in combination with 6-benzylaminopurine (BA) or isopenthenyladenine (2iP) added at the concentration $0.5,1$ and 2 $\mathrm{mg} \mathrm{L}^{-1}$. As a control LS basal medium without any hormones was applied sucrose $\left(30 \mathrm{~g} \mathrm{~L}^{-1}\right)$ and agar $\left(8 \mathrm{~g} \mathrm{~L}^{-1}\right)$ were added to the media and $\mathrm{pH}$ was adjusted to 5.8 .

Callus tissues were grown in Petri dishes. For each type of medium at least ten dishes containing explants from five seedlings were used for callus growth. The cultures were maintained in a growth chamber at $25^{\circ} \mathrm{C}$ under a 16 -h photoperiod, provided by cool white fluorescent lamps. After 30 days the mint callus induction and its characteristic features such as abundance, color, structure, tendency to form roots, shoots and necrosis grade, $10 \%$ ) and analysed by GC-FID (injection volume $1 \mu \mathrm{l}, \mathrm{HP}-\mathrm{WAX}$ and HP-5 capillary columns) and GC-MS (injection volume $0.1 \mu \mathrm{l}, \mathrm{DB}-5$ capillary column).

GC-FID analysis. GC-FID analyses were run on an HP-5890 Series II instrument equipped with HP-WAX and HP-DB-5 capillary columns $(30 \mathrm{~m} \times 0.25 \mu \mathrm{m}, 0.25$ $\mu \mathrm{m}$ film thickness), working with the following temperature program: $60^{\circ} \mathrm{C}$ for $10 \mathrm{~min}$, ramp of $5^{\circ} \mathrm{C} / \mathrm{min}$ up to $220^{\circ} \mathrm{C}$; injector and detector temperatures $250^{\circ} \mathrm{C}$; carrier gas nitrogen $(2 \mathrm{ml} / \mathrm{min})$; detector dual FID; split ratio $1: 30$; injection volume of $1 \mu \mathrm{l} ; 10 \% n$-hexane solution. Identification of the essential oil constituents was performed for both columns by comparison of their retention times with those of pure authentic samples and by means of their Linear Retention Indices (L.R.I.) relative to a series of $n$-hydrocarbons (C9-C23) on the two columns.

GC-MS analysis. GC/EI-MS analyses were performed on a Varian CP-3800 gas chromatograph equipped with an HP DB-5 capillary column (30 $\mathrm{m} \times 0.25 \mathrm{~mm}$; coating thickness $0.25 \mu \mathrm{m})$ and a Varian Saturn 2000 ion trap mass detector. Analytical conditions: injector and transfer line temperatures 220 and

Table 2. Calibration parameters of the standard compounds used in the GC-MS quantitative analysis.

\begin{tabular}{lccccc}
\hline Standard compounds & LRI & Representative chemical class & Calibration Curve Equation & $\mathrm{R}^{2}$ & Detection Limit $(\mathrm{mg} / \mathrm{mL})$ \\
\hline 2-ctanol & 995 & hydrocarbon derivatives & $y=0.4765 x+0.0071$ & 0.999 & 0.0054 \\
imonene & 1029 & monoterpene hydrocarbons & $y=0.7231 x+0.0154$ & 0.999 & 0.0022 \\
enthone & 1153 & oxygenated monoterpenes & $y=0.4350 x+0.0893$ & 0.999 & 0.0027 \\
$\beta$ & 1419 & sesquiterpene hydrocarbons & $y=0.5470 x+0.0024$ & 0.999 & 0.0063 \\
aryophyllene oxide & 1512 & oxygenated sesquiterpenes & $y=0.6454 x+0.0097$ & 0.999 & 0.0081
\end{tabular}

a $y=C_{i s} / C_{s}$ and $x=A_{i s} / A_{s}$ where $C_{s}, A_{s}=$ concentration and peak area of standard, $C_{i s}$ and $A_{i s}=$ concentration and peak area of internal standard 
$240^{\circ} \mathrm{C}$, respectively; oven temperature programmed from $60^{\circ} \mathrm{C}$ to $240^{\circ} \mathrm{C}$ at $3^{\circ} \mathrm{C} / \mathrm{min}$; carrier gas helium at $1 \mathrm{ml} /$ min; injection volume $0.1 \mu \mathrm{l}(10 \% n$-hexane solution); split ratio $1: 30$. Identification of the constituents was based on a comparison of the retention times with those of authentic samples, comparing their LRI with those of a series of $n$-hydrocarbons (C9-C30). Computer matching of the mass spectra by two commercial data bases (NIST 2000, ADAMS) as well as a home-made library built up from pure substances or known oils were used to perform identification of the volatile constituents. Moreover, the molecular weights of the identified substances were confirmed by GC/CIMS, using $\mathrm{MeOH}$ as $\mathrm{CI}$ ionizing gas.

HS-SPME-GC-MS. The HS-SPME analyses were performed with Supelco SPME devices, coated with two different kinds of fibers (PDMS, PDMS-Carboxen, 100 $\mu \mathrm{m})$ in order to sample the static headspace of a fixed portion of the freeze-dried plant material (stems, leaves, in vitro plantlets, callus) of $M$. longifolia. Each aliquot was inserted separately into a $50-\mathrm{ml}$ conic glass flask and allowed to equilibrate for $30 \mathrm{~min}$. After the equilibration time, each fiber was exposed to the sample headspace for $5 \mathrm{~min}$ at room temperature, and when the sampling was finished the fiber was withdrawn into the needle and transferred to the injection port of the GC and GC-MS system, operating in the conditions described for the essential oils, apart from the splitless injection mode and the injector temperature $\left(250^{\circ} \mathrm{C}\right)$.

Quantitative analysis. Quantification of the essential oils was conducted using an internal standard (is, nundecane) added to the volatile oil under the conditions of the GCMS analysis used for standard mixtures. Calibration curves of the analytes were performed by using standards which have chemical similarity with the compounds of interest in the volatile oils (Table 2). The correspondent regression lines (five points) of each standard in Table 2 were obtained with chromatographic injections of solutions obtained by mixing accurate volumes of the standard stock solution and an accurate volume of internal standard solution at $10 \mathrm{mg} / \mathrm{ml}(n$-hexane as solvent). The limits of detection of the standard target compounds are given in $\mathrm{mg} / \mathrm{mL}$ (Table 2). The qualiquantitative GC-MS results are given as a mass percentage composition $(\mathrm{mg} / 100 \mathrm{mg})$ of each volatile sample which was determined by the injection of a solution (0.1 $\mu \mathrm{L})$ obtained by mixing $10 \mu \mathrm{L}$ of volatile fraction, 100 $\mu \mathrm{L}$ of internal standard solution $(1 \mathrm{mg} / \mathrm{mL})$ and $n$-hexane to $1 \mathrm{~mL}$ (three measurements for sample).

The quali-quantitative results are shown in Tables 3-5.

\section{RESULTS AND DISCUSSION}

The volatile constituents emitted from field and in vitro biomass of $M$. longifolia were extracted both by hydrodistillation to obtain the essential oil (EO) and by solid phase microextraction (SPME) to sample the spontaneous aroma. The EO yields were $2.2 \% \mathrm{v} / \mathrm{w}$ for stems and $1.5 \%$ for leaves collected from adult plants of M. ongifolia.

The EO yields of in vitro plants and callus were much lower $(0.2$ and $0.4 \% \mathrm{v} / \mathrm{w}$, respectively) (Table 1$)$. However, these yields from in vitro biomass were similar or higher than those obtained from air-dried or fresh wild M. longifolia reported in the literature (Table 1). The EO composition was similar for the stems and leaves of field-grown adult plants, even if significant quantitative 
Table 4. Mass percent compositiona of $M$. longifolia essential oils obtained by hydrodistillation from in vivo and in vitro plant material.

\begin{tabular}{|c|c|c|c|c|c|c|c|c|c|}
\hline \multirow[b]{2}{*}{ Components } & \multirow[b]{2}{*}{ LRI } & \multicolumn{2}{|c|}{ Stems } & \multicolumn{2}{|c|}{ Leaves } & \multicolumn{2}{|c|}{$\begin{array}{l}\text { in vitro } \\
\text { plantlets }\end{array}$} & \multicolumn{2}{|c|}{ callus tissue } \\
\hline & & $(\%)^{a}$ & $\mathrm{RSD}^{\mathrm{b}}$ & (\%) & RSD & $(\%)$ & RSD & $(\%)$ & RSD \\
\hline 2-(E)-hexenal & 805 & 0.6 & 0.05 & 0.3 & 0.01 & 0.1 & 0.01 & & \\
\hline a-thujene & 930 & 0.4 & 0.06 & 0.7 & 0.02 & & & 0.1 & 0.00 \\
\hline a-pinene & 939 & 4.9 & 0.19 & 1.2 & 0.01 & 0.3 & 0.04 & 0.1 & 0.01 \\
\hline camphene & 954 & 0.8 & 0.07 & 0.8 & 0.01 & & & & \\
\hline sabinene & 975 & 2.3 & 0.08 & 1.1 & 0.02 & 0.7 & 0.03 & 2.1 & 0.11 \\
\hline$b$-pinene & 979 & 6.8 & 0.16 & 1.7 & 0.01 & 1.3 & 0.11 & 1.2 & 0.10 \\
\hline myrcene & 991 & 3.6 & 0.17 & 1.6 & 0.02 & 1.4 & 0.01 & 1.0 & 0.10 \\
\hline 2-octanol & 995 & 0.4 & 0.03 & 0.4 & 0.01 & 0.1 & 0.00 & 0.1 & 0.00 \\
\hline 3-carene & 1002 & 0.2 & 0.01 & & & & & & \\
\hline iso-sylvestrene & 1009 & $t^{c}$ & & 0.8 & 0.01 & & & & \\
\hline a-terpinene & 1017 & 0.9 & 0.09 & 0.7 & 0.01 & 0.4 & 0.01 & & \\
\hline$p$-cymene & 1025 & 0.4 & 0.04 & 0.7 & 0.00 & & & & \\
\hline limonene & 1029 & 15.3 & 0.57 & 5.8 & 0.29 & 1.3 & 0.01 & 0.7 & 0.10 \\
\hline 1,8-cineole & 1033 & 8.2 & 0.15 & 5.4 & 0.02 & 2.3 & 0.02 & 3.4 & 0.16 \\
\hline (Z)-b-ocimene & 1037 & 9.1 & 0.18 & 3.7 & 0.13 & & & 10.1 & 0.27 \\
\hline (E)-b-ocimene & 1050 & 8.5 & 0.13 & 3.8 & 0.11 & & & 3.0 & 0.21 \\
\hline dihydro tagetone & 1053 & & & 4.1 & 0.01 & & & & \\
\hline$g$-terpinene & 1060 & 0.3 & & 0.8 & 0.01 & 0.2 & 0.01 & & \\
\hline n-octanol & 1068 & $\mathrm{t}$ & & & & & & & \\
\hline cis-sabinene hydrate & 1069 & & & 4.1 & 0.05 & & & 2.1 & 0.11 \\
\hline camphelinone & 1070 & & & 4.1 & 0.09 & & & $\mathrm{t}$ & \\
\hline linalool & 1097 & $\mathrm{t}$ & & 4.1 & 0.02 & 0.9 & 0.13 & 4.4 & 0.20 \\
\hline$n$-nonanal & 1101 & & & 0.3 & 0.00 & & & & \\
\hline 1,3,8-p-menthatriene & 1110 & & & 0.7 & 0.01 & & & & \\
\hline 1,3,8-cis-menthatriene & 1120 & & & 0.7 & 0.01 & & & & \\
\hline allo-ocimene & 1132 & & & & & & & 1.2 & 0.10 \\
\hline menthone & 1153 & 4.7 & 0.11 & 4.2 & 0.01 & & & & \\
\hline iso-menthone & 1163 & 1.5 & & 4.1 & 0.02 & & & & \\
\hline neo-menthol & 1166 & & & 4.0 & 0.02 & & & & \\
\hline menthol & 1172 & 1.9 & & 4.3 & 0.12 & & & & \\
\hline 4-terpineol & 1177 & & & 4.1 & 0.11 & & & & \\
\hline 3-(Z)-hexenyl butanoate & 1185 & & & 0.3 & 0.01 & & & & \\
\hline a-terpineol & 1189 & 1.2 & 0.12 & 4.2 & 0.13 & 1.1 & 0.01 & & \\
\hline methyl salicylate & 1192 & & & $\mathrm{t}$ & & & & & \\
\hline cis-dihydro carvone & 1193 & & & 4.1 & 0.12 & & & & \\
\hline n-decanal & 1202 & 0.3 & 0.02 & & & & & & \\
\hline verbenone & 1205 & 1.2 & 0.03 & & & & & & \\
\hline isopulegone & 1208 & 1.2 & 0.05 & & & & & & \\
\hline cis-hexenyl isovalerate & 1235 & 1.3 & 0.10 & 4.3 & 0.21 & & & & \\
\hline pulegone & 1237 & & & & & & & & \\
\hline carvone & 1243 & 15.1 & 0.10 & 7.9 & 0.21 & & & & \\
\hline piperitone & 1253 & 2.2 & 0.01 & 4.8 & 0.04 & 3.3 & 0.12 & & \\
\hline cis-piperitone epoxide & 1254 & & & & & & & 2.4 & 0.15 \\
\hline trans-piperitone epoxide & 1256 & & & & & & & 8.0 & 0.22 \\
\hline
\end{tabular}

differences were observed. The main components were limonene and carvone both in stems (15.3 and $15.1 \%$, respectively) and leaves (5.8 and $7.9 \%$, respectively). The hydrocarbon monoterpenes such as $\alpha$-and $\beta$-pinene, 1,8 -cineole, as well as $Z$ - and E-ocimene were much more abundant in stems than in the leaf EOs (Table 4). On the other hand, the oxigenated $p$ menthene compounds, which are other typical constituents of mint spp., showed higher percentages in the leaf than in the stem EOs. The menthol/menthone ratio in the stem (0.4) and in leaf EOs (0.1) of the parent plants were similar to those reported in the literature for airdried Cretan $M$. longifolia plants (0.3-0.1), but it was much lower than found in Italian fresh samples (3.0) (Maffei, 1988; Karousou et al., 1998). Previous studies on wild extra-European $M$. longifolia, such as Asian and Australian samples, showed a menthol/menthone ratio in favour of menthone, as those plants did not produce menthol. On the other hand, wild $M$. longifolia samples from Turkey, Iran, and South Africa, had a large amount of pulegone instead of menthone or menthol. In fact, many mint species have been reported to have an efficient conversion of piperitenone to pulegone (Table 3). Pulegone (monoterpene monocyclic ketone) has been detected in several EOs of mint spp. and it is considered the precursor of another typical mint ketone, menthone, the monocyclic alcohol menthol, and the bicyclic epoxydic monoterpene menthofuran (Fig. 1). Many studies have shown that piperitenone, piperitone, and pulegone generally co-exist in the 


\begin{tabular}{|c|c|c|c|c|c|c|c|c|c|}
\hline cis-carvone oxide & 1263 & & & & & & & 2.3 & 0.11 \\
\hline trans-carvone oxide & 1276 & & & & & & & 18.9 & 0.41 \\
\hline menthyl acetate & 1295 & & & & & & & 2.6 & 0.07 \\
\hline piperitenone & 1315 & & & & & 30.4 & 0.54 & & \\
\hline piperitenone oxide & 1369 & & & & & 44.8 & 0.10 & 3.3 & 0.16 \\
\hline$b$-bourbonene & 1388 & 0.5 & 0.01 & 0.2 & 0.01 & & & & \\
\hline$b$-elemene & 1391 & 0.2 & 0.01 & 0.2 & 0.01 & & & $\mathrm{t}$ & \\
\hline$b$-caryophyllene & 1419 & 2.8 & 0.04 & 0.6 & 0.02 & & & $\mathrm{t}$ & \\
\hline phenyl ethyl butanoate & 1444 & & & 0.1 & 0.00 & & & 2.1 & 0.06 \\
\hline trans-muurola-4(14),5-diene & 1450 & $\mathrm{t}$ & & 0.1 & 0.01 & & & & \\
\hline a-humulene & 1455 & 0.2 & 0.01 & 0.1 & 0.01 & & & 1.1 & 0.05 \\
\hline (E)-b-farnesene & 1457 & $\mathrm{t}$ & & & & & & & \\
\hline cis-muurola-4(14),5-diene & 1467 & $\mathrm{t}$ & & 0.1 & 0.00 & & & & \\
\hline germacrene D & 1485 & 2.0 & 0.02 & 0.5 & 0.03 & & & 4.2 & 0.17 \\
\hline bicyclogermacrene & 1500 & 0.3 & 0.01 & 0.2 & 0.01 & & & 2.2 & 0.08 \\
\hline germacrene A & 1501 & & & 0.1 & 0.01 & & & & \\
\hline$d$-cadinene & 1523 & & & 0.1 & 0.01 & & & & \\
\hline spathulenol & 1578 & & & 0.5 & 0.01 & & & & \\
\hline caryophyllene oxide & 1583 & & & 0.5 & 0.01 & & & & \\
\hline globulol & 1585 & 0.5 & 0.02 & & & & & & \\
\hline epi-a-cubenol & 1640 & & & 0.5 & 0.03 & & & & \\
\hline a-cadinol & 1654 & & & 0.5 & 0.02 & & & & \\
\hline Total & & 99.8 & 0.27 & 99.5 & 0.17 & 99.8 & 0.16 & 98.1 & 0.49 \\
\hline
\end{tabular}

aContent of compound in $\mathrm{mg} / 100 \mathrm{mg}$ of the essential oil; ${ }^{\mathrm{B} R S D}$ relative standard deviation (triplicate analysis; $p \leq 0.05) ; \mathrm{ct}=\operatorname{traces}(\%<0.1)$.

mint essential oils (Karousou et al., 1998; Abu Al-Futuh et al., 2000), but some chemotypes of M. longifolia have been reported to contain piperitenone oxide (1,2-epoxyp-menth-4-(8)-en-3-one) as the major constituent (Maffei, 1988; Venskutonis, 1996). In the present work, piperitone was at very low levels both in the stem $(2.2 \%)$ and in leaf EOs (4.8\%), while pulegone, menthofuran, piperitenone, and piperitenone oxide were not detected. Regarding sesquiterpenes, $\beta$-caryophyllene $(2.8 \%)$ and germacrene $\mathrm{D}(2.0 \%)$ were the most abundant volatiles in stem EOs, while the same compounds dropped under $1 \%$ in the leaves of $M$. longifolia parent plants. Previous studies on $M$. longifolia $\mathrm{EO}$ reported that germacrene $\mathrm{D}$ is taining $1.0 \mathrm{mg} \mathrm{\textrm {L } ^ { - 1 }} \mathrm{BA}$ plus $0.5 \mathrm{mg} \mathrm{L}^{-1} 2,4-\mathrm{D}$. The callus obtained on this medium was creamy, fragile which is important in the case of suspension cultures. Moreover this tissue was characterized by good biomass production. The GC-MS analysis of in vitro plantlets and callus of $M$. longifolia showed a large variety of the typical volatile constituents already found in their parent plant material. Furthermore, most of these volatile constituents were also emitted spontaneously by in vitro biomass as confirmed by the SPMEGC-MS analysis carried out directly on this material (Table 5). However, significant quali-quantitative differences were observed between the in vivo and in vitro biomass. The ratio of oxides/ketones was found to be an important parameter to indicate the efficiency of the conversion from piperitenone to piperitenone oxide in the in vivo plants. Piperitone and piperitenone were not detected in the callus $\mathrm{EO}$, while their corrispondent oxides, cis- $(2.4 \%)$ and trans$(8.0 \%)$ piperitone epoxide as well as piperitenone oxide $(3.3 \%)$ were present (Tables 3-5).

Furthermore, the huge amounts of carvone which were detected in the $M$. longifolia EO of adult plants (15.1 and $7.9 \%$ in stems and leaves, respectively) were not pro-

Figure 1. General biosynthetic scheme of cyclic monoterpene ketones reported in mint species (Maffei, 1999).

a typical sequiterpene of species (Maffei, 1988; Evans, 1996; Rasooli \& GC-MS analyses confirmed these results for
the EO extracted from adult plants (Table 5). of Polish $M$. longifolia were used to establish in the induction of callus tested media (outside the
tested was noticed on all control variant). The $M$. on the medium enriched with isopenthenyladenine tic acid generally gave grow or very poor callus
growth. A slightly better effect was observed
when 6-benzylaminopurine was used as cytokinin, but the callus tis-
sues obtained were also poor. Small necroses on
explant surfaces were observed, and roots or shoots were not formed. The best effects were observed on media containing $1.0 \mathrm{mg} \mathrm{I}^{-1} \mathrm{BA}$ 西

.

\section{政}


Table 5. Relative percentage composition of M. longifolia aroma obtained from the in vivo and in vitro plant material by static HS-SPME-GC-MS.

\begin{tabular}{|c|c|c|c|c|c|c|c|c|c|}
\hline & & stems & & leaves & & in vitro & plantlets & callus & \\
\hline & LRI & PDMS & $\mathrm{CARB}^{\mathrm{b}}$ & PDMS & CARB & PDMS & CARB & PDMS & CARB \\
\hline Components & & $\%$ & $\%$ & $\%$ & $\%$ & $\%$ & $\%$ & $\%$ & $\%$ \\
\hline 2-(E)-hexenal & & & & $t^{c}$ & $\mathrm{t}$ & & & & \\
\hline a-thujene & 930 & & & 0.1 & 0.1 & $\mathrm{t}$ & & & \\
\hline a-pinene & 939 & 0.9 & & 1.5 & 1.0 & 0.3 & 0.1 & $\mathrm{t}$ & 0.1 \\
\hline camphene & 954 & 0.1 & & 0.1 & 0.1 & $\mathrm{t}$ & & & \\
\hline sabinene & 975 & 1.1 & & 1.4 & 1.1 & 0.3 & 0.2 & & \\
\hline$b$-pinene & 979 & 3.8 & 0.8 & 4.0 & 4.1 & 0.8 & $\mathrm{t}$ & 0.1 & 0.5 \\
\hline myrcene & 991 & 2.8 & 0.8 & 3.9 & 4.0 & 0.9 & 0.1 & & \\
\hline 3-octanol & 995 & 0.0 & 0.1 & 0.4 & 0.4 & $\mathrm{t}$ & & & \\
\hline 3-carene & 1003 & & & 0.1 & 0.1 & $\mathrm{t}$ & & & \\
\hline iso-sylvestrene & 1009 & $\mathrm{t}$ & $\mathrm{t}$ & & & & & & \\
\hline a-terpinene & 1017 & $\mathrm{t}$ & $\mathrm{t}$ & $\mathrm{t}$ & & 0.2 & 0.1 & & \\
\hline$p$-cymene & 1025 & 0.1 & & 0.1 & 0.1 & $\mathrm{t}$ & & & \\
\hline limonene & 1029 & 12.7 & 14.7 & 15.1 & 21.2 & 0.8 & 2.6 & 0.3 & 0.5 \\
\hline 1,8-cineole & 1033 & 20.6 & 9.8 & 23.1 & 11.2 & 1.7 & 0.4 & 2.3 & 1.9 \\
\hline (Z)-b-ocimene & 1037 & 9.6 & 3.3 & 11.9 & 12.9 & & & 6.3 & 2.1 \\
\hline 2-heptyl acetate & 1043 & & & & & & & & \\
\hline (E)-b-ocimene & 1050 & 1.3 & 0.1 & 1.0 & 2.4 & 0.3 & 0.1 & 2.7 & 2.0 \\
\hline dihydro tagetone & 1053 & & & $\mathrm{t}$ & & & & & \\
\hline$g$-terpinene & 1060 & 0.3 & & 0.2 & 0.1 & 0.1 & $\mathrm{t}$ & & \\
\hline cis-sabinene hydrate & 1070 & 0.2 & $\mathrm{t}$ & & & $\mathrm{t}$ & $\mathrm{t}$ & 1.2 & 2.5 \\
\hline camphenilone & 1072 & & & 0.2 & 0.3 & $\mathrm{t}$ & $\mathrm{t}$ & & \\
\hline 2,5-dimethyl styrene & 1099 & & & & & & & & \\
\hline linalool & 1097 & 0.4 & $\mathrm{t}$ & 0.3 & 0.5 & 0.3 & 0.1 & 3.5 & 3.9 \\
\hline$n$-nonanal & 1101 & & & 0.1 & 0.1 & & & & \\
\hline $1,3,8-p$-menthatriene & 1110 & & & 0.1 & & & & 0.9 & 1.1 \\
\hline allo-ocimene & 1120 & & & 2.1 & 1.7 & 0.4 & $\mathrm{t}$ & 0.3 & 1.2 \\
\hline isopulegol & 1150 & & & & & & & & \\
\hline menthone & 1153 & 15.3 & 31.5 & 13.8 & 17.9 & 0.1 & $\mathrm{t}$ & 0.8 & 1.1 \\
\hline iso-menthone & 1163 & 2.5 & 4.3 & 2.3 & 1.0 & 0.2 & 0.1 & 2.2 & 0.9 \\
\hline neo-menthol & 1166 & 0.1 & 0.1 & 0.2 & 0.1 & 0.2 & $\mathrm{t}$ & 2.7 & 3.8 \\
\hline (+)-menthol & 1172 & 1.5 & 2.9 & 2.0 & 1.0 & 0.1 & $\mathrm{t}$ & 1.1 & 2.3 \\
\hline$g$-terpineol & 1177 & & & & & & & 5.4 & 8.2 \\
\hline iso-menthol & 1183 & & & & & & & 4.9 & 2.1 \\
\hline$n$-decanal & 1189 & 0.1 & 0.1 & 0.2 & $\mathrm{t}$ & 0.8 & 2.1 & 2.3 & 4.2 \\
\hline verbenone & 1192 & 0.2 & 0.1 & 0.2 & 0.1 & & & 3.8 & 2.1 \\
\hline isopulegone & 1193 & 0.2 & $\mathrm{t}$ & 0.8 & 0.7 & & & & \\
\hline pulegone & 1237 & & & & & & & & $\mathrm{t}$ \\
\hline carvone & 1243 & 13.4 & 5.8 & 7.5 & 8.1 & & & 3.6 & 3.0 \\
\hline 2-(Z)-hexenyl isovalerate & 1245 & 1.1 & 0.6 & 0.1 & 0.3 & & & 2.2 & 3.1 \\
\hline 2-(E)-hexenyl isovalerate & 1247 & & & & & & & 0.8 & 0.8 \\
\hline piperitone & 1253 & 2.1 & 1.4 & 1.7 & 2.2 & 35.7 & 24.6 & 4.2 & 5.6 \\
\hline cis-piperitone epoxide & 1254 & & & & & & & 1.7 & 2.0 \\
\hline trans-piperitone epoxide & 1256 & & & & & & & 7.7 & 5.5 \\
\hline cis-carvone oxide & 1263 & & & & & & & 1.1 & 0.5 \\
\hline
\end{tabular}

duced in the callus $\mathrm{EO}$ in favour of cis- $(2.3 \%)$ and trans$(18.9 \%) \quad$ carvone oxides. Although the $M$. longifolia callus did not show limonene and carvone as main constituents like their mother plants, they were characterized by the highest oxidative status of carvone and piperitone. In addition, the scarce amount of limonene $(0.7 \%)$ and the lack of terpinolene, which are the precursors of piperitenone and carvone, could be justified by the complete transformation of these two latter compounds into their corrispondent oxides (Fig. 1). Regarding the in vitro plantlets, they showed the specific terpenes of $M$. longifolia generally reported in the literature.

Piperitenone $(30.4 \%)$ and piperitenone oxide $(44.8 \%)$ were the main constituents in their EOs (Table 4). However, as mentioned above, neither these compounds was not detected in the Polish $M$. longifolia mother plants. Nevertheless, the established in vitro plantlets could be considered similar to a chemotype of $M$. longifolia rich in piperitenone oxide $(75 \%)$. In fact, a chemotype of $M$. longifolia Hudson (L.) particularly rich in piperitenone oxide $(77 \%)$ was selected from populations growing wild in Piedmont Valley (Italy) (Maffei, 1988) and Lithuania (Venskutonis, 1996). 


\begin{tabular}{llllllllll} 
trans-carvone oxide & 1276 & & & & & & & 16.1 & 14.3 \\
menthyl acetate & 1295 & 0.4 & 1.7 & 0.5 & 0.3 & & & 2.4 & 3.9 \\
iso-ascaridol & 1303 & & & & & & & 1.5 & 0.9 \\
piperitenone & 1343 & & & & & 0.8 & 1.0 & 1.8 & 0.9 \\
piperitenone oxide & 1369 & & & $\mathrm{t}$ & & 49.8 & 48.9 & 2.7 & 3.0 \\
b-bourbonene & 1388 & 0.5 & 0.5 & 0.3 & 0.2 & & & 0.6 & 0.5 \\
b-elemene & 1391 & 0.1 & 0.3 & 0.1 & 0.1 & 0.7 & 0.2 & 0.8 & 0.9 \\
b-caryophyllene & 1419 & 1.5 & 2.5 & 1.3 & 2.1 & 2.1 & 4.4 & 1.0 & 1.1 \\
trans-muurola 3,5-diene & 1454 & $\mathrm{t}$ & 0.1 & & & & & & \\
a-humulene & 1455 & 0.1 & 0.2 & $\mathrm{t}$ & & 0.2 & 0.5 & 0.5 & 0.6 \\
cis-muurola-4(14),5-diene & 1467 & 0.2 & $\mathrm{t}$ & 0.1 & 0.2 & & & 0.6 & 0.9 \\
germacrene D & 1485 & 0.5 & 1.7 & 0.8 & 0.7 & 1.1 & 3.0 & 0.4 & 5.3 \\
bicyclogermacrene & 1500 & 0.2 & 3.7 & $\mathrm{t}$ & & 1.0 & 8.5 & 2.4 & 4.0 \\
caryophyllene oxide & 1583 & 0.1 & 2.3 & $\mathrm{t}$ & & & & & \\
Total & & 94.0 & 89.3 & 97.6 & 96.4 & 98.9 & 97.0 & 93.1 & 97.3 \\
\hline
\end{tabular}

aPDMS and Carboxen fibers, $100 \mathrm{~mm}$; ${ }^{\circ} \mathrm{RSD}$ relative standard deviation (triplicate analysis; $p \leq 0.05$ ); $\mathrm{ct}^{\mathrm{P}}=$ traces $(\%<0.1)$.

In our work, the in vitro plantles of $M$. longifolia showed an aromatic fingerprint characterized by huge amounts of piperitone and piperitenone oxide $(75 \%)$ with a clear reduction in other typical $p$-menth-compounds detected in their parent plants (Tables 3-4). Furthermore, the in vitro callus and plantlets did not show pulegone and its major metabolite menthofuran. The present study is the first report on the aromatic profiling of $M$. longifolia as in vivo and in vitro plant material. Both types of in vitro plant material, callus and plantlets, were characterized by a lack of pulegone and methofurane. It is important to point out that the EFSA Scientific Committee on Food was recently asked to provide scientific advice on the implications for human health of chemically defined flavouring substances used in or on foodstuffs in the EU Member States. According to EU Flavourings List, pulegone and menthofuran cannot be used as flavouring substances (Moorthy, 1991; Tisserand \& Balacs, 1995; Nair, 2001; JECFA, 2009). Therefore, the in vitro plantlets and callus of $M$. longifolia which did not contain pulegone and menthofurane preserved an important safety feature of their parent plants and they may be qualified as alternative flavouring ingredients.

\section{Acknowledgements}

This work was financially supported by the European Community NUTRASNACK, 6FP project.

\section{REFERENCES}

Abu Al-Futuh IM, Abdulmageed OH, Jamil RM, Avato PA (2000) Piperitenone oxide chemotype of Mentha longifolia (L.) Huds. growing wild in Jordan. I Essent Oil Res 12: 530-532.

Baser KHC, Kürkcüoglu M, Tarimcilar G, Kaynak G (1999) Essential Oils of Mentha Species from Northern Turkey. I Essent Oil Res 11: 579-588.

Dorman HJ, Kosar M, Kahlos K, Holm Y, Hiltunen R (2003) Antioxidant prosperities and composition of aqueous extracts from Mentha species, hybrids, varieties and cultivars. I Agric Food Chem 51: 4563-4569.
(Boriss.) Rech. from Iran. J Essent Oil Res 14: 107-108.

Evans WC (1996) In Trease and Evans' Pharmacognosy. 14th edn, pp 237-276. W.B. Saunders Co. Ltd. London, UK. Fleisher Z, Fleisher A (1998) Volatile extract of Mentha longifolia growing in Israel. J Essent Oil Res 10: 647-648.

Gulluce M, Sahin F, Sokmen M, Ozer H, Daferera D, Sokmen A, Polissiou M, Adiguezel A, Ozkan H (2007) Antimicrobical and antioxidant properties of the essential oils and methanol extract from Mentha longifolia L. ssp. Longifolia. Food Chem 103: 1449-1456.

Ikram M, Haq I (1980) Screening of medicinal plants for antimicrobial activity. Fitoterapia 51: 231-235.

Jaimand K, Rezaee MB (2002) Chemical Constituents of Essential Oils from Mentha longifolia (L.) Hudson var. asiatica

ECFA, 55th meeting (2009) Scientific Opinion of the Panel on Food Contact Material, Enzymes, Flavourings \& Processing Aids on a request from the Commission on Flavouring Group Evaluation.

Karousou R, Lanaras T, Kokkini S (1998) Piperitone Oxide-Rich Essential Oils from Mentha longifolia subsp. Petiolata and $M . \times$ villosonervata Grown Wild on the Island of Crete. I Essent Oil Res 10: 375-379.

Kokkini S, Papageorgiou V (1988) Costituents of essential oils from Mentha longifolia growing wild Greece. Planta Medica 54: 59-60.

Lamaison JL, Petitjean-Freytet C, Duband F, Carnat AP (1991) Rosmarinic acid content and antioxidant activity of French Lamiaceae. Fitoterapia 62: 166-171.

Lawrence BM (1981) The biology and Chemistry of Mentha genus. In Essential oils 1979-1980. Allured Publ. Corp., pp 183-139. Carol Stream, IL, USA

Linsmayer EM, Skoog F (1965) Organic growth factor requirements of tobacco tissue cultures. Physiol Plantarum 18: 100-127.

Maffei MA (1988) Chemotype of M. longifolia L. Hudson particulary rich in piperitenone oxide. Flav Fragr J 3: 23-24.

Maffei M (1999) Biosintesi dei terpenoidi. In Metabolismo e prodotti secondari delle piante. UTET Ed., Torino (in Italian).

Mastelic J, Jerkovic I (2002) Free and glicosidically bound volatiles of Mentha longifolia growing in Croatia. Chem Nat Comp 38: 561-564.

Mathela CS, Padalia RC, Chanotija CS, Tiwari A (2005) Carvone rich Mentha longifolia (Linn.): Chemical variation and commercial potential. J Ess Oil-Bearing Plants 8: 130-133.

Mimica Dukic N, Bozin B, Sokovic M, Mihailovic B, Matavulj M (2003) Antimicrobial and antioxidant activities of three Mentha species essential oils. Planta Medica 69: 413-419.

Mimica-Dukic N, Jacovljevic V, Mira P, Gasic O, Szabo A (1996) Pharmacological studies on Mentha longifolia phenolic extracts. Int J Pharm 34: 359-364.

Moorthy B (1991) Toxicity and metabolism of R-(+)-pulegone in rats: its effects on hepatic cytochrome $\mathrm{P} 450$ in vivo and in vitro. I Indian Inst Sci 71: 76-78.

Nair B (2001) Final report on the safety assessment of Mentha piperita (peppermint) oil, Mentha piperita (peppermint) leaf extract, Mentha piperita (peppermint) leaf, and Mentha piperita (peppermint) leaf water. Int J Toxicol 20: 61-73.

Oyedeji AO, Afolayan AJ (2006) Chemical composition and antibacterial activity of the essential oil isolated from South Africa Mentha longifolia (L.) L. subsp. Capensis (Thunb.) Briq J Essent Oil Res 18: 57-59.

Rasooli I, Rezaei MB (2002) Bioactivity and chemical properties of essential oils from Zataria multiflora Boiss and Mentha longifolia (L.) Huds. J Essent Oil Res 14: 141-146.

Tisserand R, Balacs T (1995) In: Essential Oil Safety: a guide for health care professionals. London, Churchill Livingstone.

Venskutonis PR (1996) A chemotype of Mentha longifolia L. from Lithuania rich in piperitone oxide. J Essent Oil Res 8: 91-95. 